\title{
Correction to: Eye-color and Type-2 diabetes phenotype prediction from genotype data using deep learning methods
}

Muhammad Muneeb ${ }^{\dagger}$ and Andreas Henschel ${ }^{* \dagger}$

The original article can be found online at https:// doi.org/10.1186/s1285 9-021-04077-9.

*Correspondence:

andreas.henschel@ku.ac.ae ${ }^{\dagger}$ Muhammad Muneeb and Andreas Henschel have contributed equally to this work

Department of Electrical Engineering and Computer Science, Center

for Biotechnology Khalifa University, Khalifa University of Science and Technology, Abu Dhabi, United Arab Emirates

\section{Correction to: BMC Bioinformatics (2021) 22:198 \\ https://doi.org/10.1186/s12859-021-04077-9}

Following the publication of the original article [1], errors were identified in the affiliation and funding note.

The changes have been highlighted in bold typeface.

Affiliation:

Department of Electrical Engineering and Computer Science, Center for Biotechnology Khalifa University, Khalifa University of Science and Technology, Abu Dhabi, United Arab Emirates.

Funding note:

The study is funded by Khalifa University Collaborative Internal Research Award CIRA-2019-076.

The original article [1] has been corrected.

Published online: 11 June 2021

Reference

1. Muneeb M, Henschel A. Eye-color and Type-2 diabetes phenotype prediction from genotype data using deep learning methods. BMC Bioinformatics. 2021;22:198. https://doi.org/10.1186/s12859-021-04077-9.

Publisher's Note

Springer Nature remains neutral with regard to jurisdictional claims in published maps and institutional affiliations.

C The Author(s), 2021. Open Access This article is licensed under a Creative Commons Attribution 4.0 International License, which permits use, sharing, adaptation, distribution and reproduction in any medium or format, as long as you give appropriate credit to the original author(s) and the source, provide a link to the Creative Commons licence, and indicate if changes were made. The images or other third party material in this article are included in the article's Creative Commons licence, unless indicated otherwise in a credit line to the material. If material is not included in the article's Creative Commons licence and your intended use is not permitted by statutory regulation or exceeds the permitted use, you will need to obtain permission directly from the copyright holder. To view a copy of this licence, visit http:// creativecommons.org/licenses/by/4.0/. The Creative Commons Public Domain Dedication waiver (http://creativecommons.org/publi cdomain/zero/1.0/) applies to the data made available in this article, unless otherwise stated in a credit line to the data. 